\title{
EVALUASI PELAKSANAAN PEMBELAJARAN MENGGUNAKAN MODEL CIPP PADA MATA PELAJARAN PRODUKTIF KOMPETENSI KEAHLIAN MULTIMEDIA DI SMK
}

\author{
Amidatus Shollihat Jamil \\ Amat Mukhadis \\ Waras
}

\begin{abstract}
Abstrak: Tujuan penelitian adalah untuk mengevaluasi pelaksanaan pembelajaran produktif kompetensi multimedia di SMK, ditinjau dari aspek context, input, proses, dan produk. Rancangan penelitian yang digunakan adalah penelitian multi situs dengan subjek penelitian dilakukan dengan teknik purposive sampling dan menetapkan kepala sekolah, wakil kepala sekolah bidang sarpras dan kurikulum, kepala kompetensi keahlian, guru produktif multimedia, dan siswa kelas XI Kompetensi Keahlian Multimedia SMKN 1 Grati dan SMKN 1 Purwosari Pasuruan sebagai subjek penelitian. Teknik pengumpulan data menggunakan angket, observasi dan wawancara. Teknik analisis data menggunakan analisis deskriptif kualitatif dengan analisis multisitus. Hasil penelitian menunjukkan bahwa ada standar yang harus disetarakan, mulai dari kebijakan pendirian kompetensi keahlian yang bias berdampak pada proses pembelajaran hingga output dari proses pembelajaran.
\end{abstract}

Kata-kata Kunci: evaluasi, model CIPP, mata pelajaran produktif, SMK, multimedia

\begin{abstract}
Evaluating the Implementation of CIPP Model in the Productive Courses of the Multimedia Competence in Vocational High School. The study aimed to evaluate the productive courses of multimedia competence in Vocational High School based on the aspects of context, input, process, and product. The subjects of this multi-site research were selected using purposive sampling, including the principal, the vice principals of curriculum and facilities and infrastructure, the head of vocational competency, the multimedia productive teachers, and the eleventh-grade students of Multimedia program in Public Vocational High School 1 Grati and Public Vocational High School 1 Purwosari, Pasuruan. Data were collected using questionnaire, observation and interview. Qualitative data were analyzed using descriptive, multi-site analysis. The results showed that there were standards that must be equalized, starting from the policy for establishing vocational competence skills that affect the learning process and the learning outcome.
\end{abstract}

Keywords: evaluation, CIPP model, productive courses, SMK, multimedia

$\mathrm{K}^{\mathrm{w}}$

urikulum SMK berisi mata pelajaran wajib, mata pelajaran kejuruan, muatan lokal dan pengembangan diri. Dalam penyusunannya dibagi menjadi tiga kelompok, yaitu kelompok adaptif, normatif, dan produktif. Kelompok normatif sebagai salah satu kelompok mata pelajaran yang ada di SMK, dialokasikan dengan menitikberatkan pada pendidikan norma, sikap, dan perilaku yang harus di-

Amidatus Sholihat Jamil adalah Dosen STMK Bangil Pasuruan. Alamat Kampus: Jl. Bader No. 9 Kalirejo, Bangil, Pasuruan, Jawa Timur. Email: sparklingamidah@gmail.com. Amat Mukhadis dan Waras adalah Dosen Jurusan Teknik Mesin Universitas Negeri Malang. Alamat Kampus: Jl. Semarang No. 5 Malang 65145 . 
tanamkan dan dilatih. Kelompok adaptif merupakan kelompok mata pelajaran yang menitikberatkan pada pemahaman dan penguasaan konsep, serta prinsip dasar ilmu pengetahuan dan teknologi. Kelompok adaptif diberikan agar siswa tidak hanya memahami tentang suatu pekerjaan dan mengetahui cara pekerjaan dilakukan, tetapi memberi pemahaman dan penguasaan alasan/dasar/tujuan tersebut dilakukan sehingga mereka dapat bekerja dengan lebih baik.

Sementara itu, kelompok produktif merupakan kelompok mata pelajaran yang berfungsi membekali siswa agar memiliki kompetensi sesuai Standar Kompetensi Kerja Nasional Indonesia (SKKNI) atau yang disepakati oleh forum yang mewakili dunia usaha dan industri atau asosiasi profesi. Kelompok produktif bersifat melayani permintaan dunia usaha dan industri. Hal ini sesuai dengan tujuan SMK yaitu menyiapkan siswa atau lulusan yang siap memasuki dunia kerja dan mampu mengembangkan sikap profesional di bidang keahliannya. Lulusan SMK diharapkan menjadi individu yang produktif, mampu bekerja menjadi tenaga kerja menengah dan memiliki kesiapan untuk menghadapi persaingan kerja. Kelompok produktif terdiri dari mata pelajaran dasar kompetensi kejuruan dan kompetensi kejuruan. Kelompok produktif diberikan secara spesifik sesuai dengan kebutuhan setiap kompetensi keahlian.

Di sisi lain permasalahan ditemukan oleh Djohar (2003) bahwa peta kompetensi SMK tidak luwes terhadap perubahan, memiliki keterampilan tunggal yang cepat usang, dan tidak mampu mengembangkan dirinya. Dalam rangka mengantisipasi masalah tersebut, maka perlu dikembangkan program diklat yang cocok diterapkan di SMK untuk meningkatkan pencapaian ketuntasan kompetensi kejuruan yang relevan dengan tuntutan pembangunan, masyarakat, dunia usaha, dan industri.
Upaya peningkatan proses pembelajaran, tentunya dilakukan oleh seluruh masyarakat yang berada pada lingkungan pendidikan, termasuk di dalamnya guru, siswa, orang tua siswa, kepala sekolah hingga tenaga kependidikan. Untuk melakukan perbaikan proses pembelajaran tentunya harus ada evaluasi mengenai proses pembelajaran yang telah berlangsung sebelumnya. Sehingga untuk mengevaluasi proses pembelajaran perlu perencanaan secara mendalam mengenai tujuan evaluasi hinggga hasil akhir yang akan dievaluasi (Mawarsari dan Prihaswati, 2014).

Kompetensi Keahlian Multimedia merupakan salah satu program yang ada pada kelompok mata pelajaran produktif di SMK. Kompetensi Keahlian Multimedia merupakan salah kompetensi keahlian yang cukup diminati di Kabupaten Pasuruan. Kabupaten Pasuruan merupakan kabupaten berkembang di Provinsi Jawa Timur yang selalu meningkatkan pemerataan kesempatan belajar dan meningkatkan mutu pendidikan di semua jenjang.

SMK telah banyak didirikan baik di kota maupun kabupaten, khususnya wilayah Jawa Timur. SMKN 1 Grati merupakan sekolah yang cukup lama didirikan di Kabupaten Pasuruan, tepatnya berada di Jalan Raya Ngopak. Kabupaten Pasuruan merupakan salah satu kabupaten yang terletak di wilayah Jawa Timur. Kompetensi Keahlian Multimedia merupakan kompetensi kehalian baru yang pertama kali dibuka pada tahun 2011 di SMKN 1 Grati. Selain SMKN 1 Grati, ada beberapa SMK Negeri di Kabupaten Pasuruan yang juga menawarkan Kompetensi Keahlian Multimedia, salah satunya adalah SMKN 1 Purwosari yang sudah lebih dulu mendirikan Kompetensi Keahlian Multimedia.

Selama ini belum pernah dilakukan evaluasi pembelajaran produktif di SMK Negeri di Kabupaten Pasuruan khususnya pada Kompetensi Keahlian Multimedia. 
Diadakan evaluasi, diharapkan dapat diketahui sejauh mana pelaksanaan pembelajaran produktif multimedia di SMKN 1 Grati yang selama kurang lebih menginjak tahun ketiga ini berjalan. Model evaluasi yang digunakan adalah CIPP Model, Context, Input, Procces, Product. Model CIPP hampir sama dengan model Stake's dan CSE-UCLA (Center for Study of Evaluation at the University of California at Los Angeles) di mana ketiganya cenderung komprehensip dan mulai dari proses evaluasi selama tahap perencanaan dari pengembangan program (Kaufman dan Thomas, 1980:123).

Kegiatan evaluasi mencakup dari segi pelaksanaan pembelajaran. Hal yang perlu dievaluasi dari segi pelaksanaan pembelajaran terdiri dari empat dimensi menurut model CIPP, yaitu context (konteks), input (input), process (proses), outcome (produk). Untuk dimensi konteks difokuskan pada kebijakan penyediaan kompetensi keahllian, kondisi geografis sosial ekonomi siswa dan daya dukung masyarakat terhadap adanya Kompetensi Keahlian Multimedia di SMK, untuk dimensi input difokuskan pada input SDM (guru dan siswa) serta sumber daya lain (dana, peralatan, perlengkapan, dan bahan) Kompetensi Keahlian Multimedia di SMK.

Sedangkan untuk dimensi proses difokuskan pada pelaksanaan pembelajaran (meliputi perencanaan, pelaksanaan, dan evaluasi) pada pelaksanaan pembelajaran mata pelajaran produktif pada Kompetensi Keahlian Multimedia di SMK, untuk dimensi produk difokuskan pada hasil belajar mata pelajaran produktif multimedia yang bersifat akademik dan masalah serta hambatan yang dihadapi siswa dalam pelaksanaan pembelajaran mata pelajaran produktif multimedia di SMK. Hal inilah yang menjadikan evaluasi ini dilakukan sehingga tujuan dari evaluasi ini adalah untuk mengungkap pelaksanaan pembelajaran mata pelajaran produktif kompetensi keahlian multimedia di SMK.

\section{METODE}

Rancangan penelitian yang digunakan adalah penelitian multi situs dengan menggunakan model CIPP yang berorientasi pada pendekatan evaluasi program yang berorientasi pada manajemen yaitu suatu gambaran yang menunjukkan prosedur dan proses pelaksanaan program. Penelitian ini mencakup evaluasi mulai dari latar belakang pendirian Kompetensi Keahlian Multimedia hingga hasil belajar mata pelajaran produktif, penelitian ini ditujukan untuk memperoleh hasil berupa penilaian/pertimbangan (judgement) dan keputusan (decision).

Model evaluasi yang digunakan dalam penelitian ini adalah model evaluasi CIPP dengan subjek penelitian siswa Kelas XI multimedia, guru produktif multimedia, kepala sekolah, wakil kepala bidang kurikulum, kesiswaan, sarana prasarana, dan manajemen mutu di SMKN 1 Grati dan SMKN 1 Purwosari. Penelitian ini dianalisis menggunakan analisis kualitatif multisitus, dengan pelaksanaan penelitian tetap mengacu pada komponenkomponen yang dievaluasi. Aspek masing-masing komponen tersebut dijabarkan pada Tabel 1.

Teknik pengumpulan data yang digunakan meliputi wawancara, observasi, dan studi dokumentasi. Data yang terkumpul melalui ketiga teknik tersebut diorganisis, ditafsir, dan dianalisis berulang ulang baik melalui analisis dalam situs maupun analisis lintas situs guna menemukan proposisi temuan penelitian. Analisis data dimulai dengan menelaah seluruh data yang dikumpulkan dari berbagai sumber, yaitu dari hasil pengamatan, wawancara dan studi dokumentasi. Data yang dikumpulkan tidak akan memberikan makna yang berarti apabila tidak dianalisis. Analisis data untuk komponen 
Tabel 1. Komponen Pelaksanaan Pembelajaran Mata Pelajaran Produktif Multimedia di SMK dan Indikator

\begin{tabular}{ll}
\hline Komponen & \multicolumn{1}{c}{ Indikator } \\
\hline Context & 1. Kebijakan dalam penyediaan Kompetensi Keahlian Multimedia \\
& 2. Kondisi geografis dan sosial ekonomi siswa Kompetesi Keahlian \\
Multimedia & \\
3. Daya dukung masyarakat terhadap adanya Kompetesi Keahlian \\
Multimedia
\end{tabular}

(Diadaptasi dari sumber: Mulyatiningsih, 2012)

konteks, input, dan proses dilakukan dengan teknik analisis kualitatif secara induktif, yaitu dengan cara membandingkan antara data yang terkumpul di lapangan dengan ketentuan proses pelaksanaan pembelajaran produktif yang sudah ditentukan oleh pemerintah. Mengingat penelitian ini dilakukan pada dua sekolah, maka dalam menganalisis data dilakukan melalui dua tahap, yaitu: (1) analisis data situs tunggal/individu, dan (2) analisis data lintas situs.

\section{HASIL}

Pertama akan dipaparkan temuan penelitian dalam situs. Situs yang pertama yakni di SMK Negeri 1 Purwosari dengan komponen yang pertama dijabarkan adalah komponen konteks. Dari paparan data di SMK Negeri 1 Purwosari, ditemukan sejumlah temuan penelitian dengan komponen konteks indikator kebijakan penyediaan Kompetensi Keahlian Multimedia, kondisi geografis dan sosial ekonomi siswa Kompetensi Keahlian Multimedia, dan daya dukung masyarakat ter- hadap adanya Kompetensi Keahlian Multimedia, temuan-temuan tersebut adalah: (1) Kepala sekolah bersama wakil kepala bidang manajemen mutu mempelajari rencana strategi Kabupaten Pasuruan, (2) Kepala sekolah melakukan analisis SWOT untuk mengetahui kekuatan, kelemahan, peluang dan ancaman apa ketika Kompetensi Keahlian Multimedia didirikan, (3) Wakil kepala bidang manajemen mutu membuat proposal yang dilatar belakangi hasil analisis SWOT untuk kemudian diajukan kepada dinas pendidikan kabupaten Pasuruan, (4) untuk melengkapi kebutuhan pendirian kompetensi keahlian, kepala sekolah bersama wakil kepala bidang manajemen mutu melakukan studi kelayakan wilayah sekitar sekolah kemudian meluas ke wilayah kabupaten.

Selanjutnya temuan-temuan diatas, disusun menjadi proposisi tentang pendirian Kompetensi Keahlian Multimedia di SMK Negeri 1 Purwosari, yang diformulasikan sebagai berikut. Proposisi: Pendirian Kompetensi Keahlian Multimedia dilakukan dengan beberapa tahapan, diawali dengan analisis SWOT, studi 
kelayakan wilayah, menganalisis daya dukung masyarakat, kemudian hasil dari keseluruhan dijadikan latar belakang dalam proposal pengajuan pendirian Kompetensi Keahlian Multimedia kepada Dinas Pendidikan Kabupaten Pasuruan. Komponen yang kedua dijabarkan adalah Komponen Input.

Dari paparan data di SMK Negeri 1 Purwosari, ditemukan sejumlah temuan penelitian dengan komponen input indikator sumber daya manusia dan sumber daya lain Kompetensi Keahlian Multimedia, temuan-temuan tersebut adalah: (1) yang dapat menjadi guru produktif multimedia di SMK Negeri 1 Purwosari adalah lulusan universitas negeri, dan telah lulus tes tulis dan wawancara di SMK Negeri 1 Purwosari, (2) yang dapat menjadi siswa Kompetensi Keahlian Multimedia di SMK Negeri 1 Purwosari adalah yang lulus dalam tes masuk Kompetensi Keahlian Multimedia SMK Negeri 1 Purwosari dengan nilai minimum 78 dan tidak ada jalur khusus untuk hal tersebut, (3) sumber daya lain sangat diperlukan untuk menunjang proses pembelajaran produktif multimedia di SMK Negeri 1 Purwosari, seperti dana yang cukup untuk melengkapi sarana prasarana yang ada.

Selanjutnya temuan-temuan di atas, disusun menjadi proposisi tentang inputan sumber daya kompetensi keahlian multimedia di SMK Negeri 1 Purwosari, yang diformulasikan sebagai berikut. Proposisi: ada tes yang dilakukan untuk menjamin kualitas guru produktif dan siswa Kompetensi Keahlian Multimedia yang didalamnya ada beberapa syarat fokus untuk Kompetensi Keahlian Multimedia, yang kemudian didukung dengan sumber daya lain seperti pendanaan dan sarana prasarana.

Komponen yang ketiga dijabarkan adalah komponen proses. Dari paparan data di SMK Negeri 1 Purwosari, ditemukan sejumlah temuan penelitian dengan komponen proses indikator perencanaan, pelaksanaan, dan evaluasi pembelajaran mata pelajaran produktif Kompetensi Keahlian Multimedia, temuan-temuan tersebut adalah: (1) guru produktif menyusun RPP dan perangkat administrasi pembelajaran lainnya berdasarkan SK/KD, (2) proses pembelajaran yang dilaksanakan di SMK Negeri 1 Purwosari berlangsung tidak hanya di kelas, bengkel/laboratorium, tetapi juga di industri pada saat siswa melaksanakan praktik kerja industri, (3) guru produktif menentukan nilai KKM untuk mata pelajaran Produktif Multimedia sebagai tolok ukur evaluasi ketuntasan belajar siswa, apabila dari hasil evaluasi masih di bawah nilai KKM maka akan dilakukan remedial atau perbaikan hingga nilai siswa mencapai KKM.

Selanjutnya temuan-temuan di atas, disusun menjadi proposisi tentang proses pelaksanaan pembelajaran mata pelajaran Produktif Kompetensi Keahlian Multimedia di SMK Negeri 1 Purwosari, yang diformulasikan sebagai berikut. Proposisi: proses pelaksanaan pembelajaran mata pelajaran Produktif Kompetensi Keahlian Multimedia di SMK Negeri 1 Purwosari dibagi menjadi tiga tahapan yaitu perencanaan yang ditunjukkan dalam pembuatan RPP guru produktif kemudian diaplikasikan dalam proses pembelajaran, setelah itu untuk mengetahui hasil belajar siswa dilakukan evaluasi beserta perbaikannya apabila ada nilai di bawah KKM.

Komponen yang terakhir dijabarkan adalah komponen produk. Dari paparan data yang telah disampaikan, ditemukan sejumlah temuan penelitian pada komponen output indicator hasil belajar dan hambatan belajar siswa, temuan-temuan tersebut adalah: (1) ada perbedaan yang signifikan dalam hal hambatan belajar siswa yang didalamnya mencakup minat, kondisi sosial ekonomi, interaksi guru, sarana dan prasarana, dan penyajian materi, (2) hasil belajar yang ditunjukkan di nilai raport siswa terlihat lebih menonjol 
yakni berkisar 80 yaitu di atas KKM mata pelajaran Produktif Multimedia. Selanjutnya temuan-temuan di atas, disusun menjadi proposisi tentang proses pelaksanaan pembelajaran mata pelajaran Produktif Kompetensi Keahlian Multimedia di SMK Negeri 1 Purwosari, yang diformulasikan sebagai berikut. Proposisi: proses pelaksanaan pembelajaran mata pelajaran produktif Kompetensi Keahlian Multimedia di SMK Negeri 1 Purwosari menghasilkan hasil belajar yang cukup baik ditunjukkan dengan nilai raport siswa yang berkisar pada nilai 80 , namun siswa memiliki hambatan belajar lebih tinggi ditinjau dari beberapa faktor. Selanjutnya akan dipaparkan temuan penelitian dalam situs yang kedua. Situs yang kedua yakni di SMK Negeri 1 Grati dengan komponen yang pertama dijabarkan adalah Komponen konteks.

Dari paparan data di SMK Negeri 1 Grati, ditemukan sejumlah temuan penelitian dengan komponen konteks indikator kebijakan penyediaan Kompetensi Keahlian Multimedia, kondisi geografis, dan sosial ekonomi siswa Kompetensi Keahlian Multimedia, dan daya dukung masyarakat terhadap adanya Kompetensi Keahlian Multimedia, temuan-temuan tersebut adalah: (1) kepala sekolah bersama wakil kepala bidang manajemen mutu melakukan analissis kebutuhan pasar, (2) wakil kepala bidang manajemen mutu melakukan analisis terhadap keberadaan kompetensi keahlian yang sama di SMK sekitar SMK Negeri 1 Grati, (3) kondisi geografis dan sosial ekonomi siswa Kompetensi Keahlian Multimedia di SMK Negeri 1 Grati tidak hanya dipandang dari lingkup kecil saja, melainkan juga lingkup yang lebih luas hingga skala nasional, (4) daya dukung masyarakat terhadap adanya Kompetensi Keahlian Multimedia di SMK Negeri 1 Grati, salah satunya ditunjukkan dengan banyaknya masyarakat yang menyekolahkan putra putrinya di kompetensi keahlian SMK Negeri 1 Grati.

Selanjutnya temuan-temuan tersebut, disusun menjadi proposisi tentang pendirian Kompetensi Keahlian Multimedia di SMK Negeri 1 Grati, yang diformulasikan sebagai berikut. Proposisi: pendirian Kompetensi Keahlian Multimedia dilakukan dengan beberapa tahapan, diawali dengan analisis kebutuhan pasar, mempersiapkan wilayah keterserapan lulusan Kompetensi Keahlian Multimedia sampai skala nasional, dan daya dukung masyarakat sekitar dapat menjadi nilai tambah bagi keberadaan Kompetensi Keahliah Multimedia.

Komponen yang kedua dijabarkan adalah komponen input. Dari paparan data di SMK Negeri 1 Grati, ditemukan sejumlah temuan penelitian dengan komponen input indikator sumber daya manusia dan siumber daya lain Kompetensi Keahlian Multimedia, temuan-temuan tersebut adalah: (1) siapapun dapat menjadi guru produktif multimedia di SMK Negeri 1 Grati asalkan memiliki latar belakang pendidikan yang dianggap linier dan SMK Negeri 1 Grati masih membutuhkan; (2) calon siswa Kompetensi Keahlian Multimedia diharuskan memiliki pengetahuan dasar tentang dunia IT dan calon siswa tidak boleh buta warna; dan (3) Sumber daya lain sangat diperlukan untuk menunjang proses pembelajaran produktif multimedia di SMK Negeri 1 Grati, diantaranya untuk pengadaan sarana dan prasarana.

Selanjutnya temuan-temuan di atas, disusun menjadi proposisi tentang inputan sumber daya kompetensi kehalian multimedia di SMK Negeri 1 Grati, yang diformulasikan sebagai berikut. Proposisi: Ada tes khusus yang dilakukan untuk menjamin kualitas guru produktif, tetapi untuk penerimaan siswa Kompetensi Keahlian Multimedia didalamnya ada beberapa syarat fokus untuk Kompetensi Keahlian Multimedia, yang kemudian di- 
dukung dengan sumber daya lain seperti pendanaan dan sarana prasarana.

Komponen yang ketiga dijabarkan adalah komponen proses. Dari paparan data di SMK Negeri 1 Grati, ditemukan sejumlah temuan penelitian dengan komponen proses indikator perencanaan, pelaksanaan, dan evaluasi pembelajaran mata pelajaran produktif Kompetensi Keahlian Multimedia, temuan-temuan tersebut adalah: (1) pada awal tahun pelajaran, guru membuat RPP sebagai bentuk perencaan pembelajaran sesuai dengan SK/ KD yang diajarkan; (2) proses pembelajaran yang dilaksanakan di SMK Negeri 1 Grati berlangsung tidak hanya di kelas, bengkel/laboratorium, tetapi juga di industri pada saat siswa melaksanakan praktik kerja industri; dan (3) guru produktif menentukan nilai KKM untuk mata pelajaran produktif multimedia sebagai tolok ukur evaluasi ketuntasan belajar siswa, apabila dari hasil evaluasi masih di bawah nilai KKM maka akan dilakukan remedial satu kali, kemudian siswa dianggap lulus dan tuntas KKM.

Selanjutnya temuan-temuan di atas, disusun menjadi proposisi tentang proses pelaksanaan pembelajaran mata pelajaran Produktif Kompetensi Keahlian Multimedia di SMK Negeri 1 Grati, yang diformulasikan sebagai berikut. Proposisi: proses pelaksanaan pembelajaran mata pelajaran Produktif Kompetensi Keahlian Multimedia di SMK Negeri 1 Grati dibagi menjadi tiga tahapan yaitu perencanaan yang ditunjukkan dalam pembuatan RPP guru produktif kemudian diaplikasikan dalam proses pembelajaran, setelah itu untuk mengetahui hasil belajar siswa dilakukan evaluasi beserta perbaikannya apabila ada nilai di bawah KKM.

Komponen yang terakhir dijabarkan adalah komponen produk. Dari paparan data yang telah disampaikan, ditemukan sejumlah temuan penelitian pada komponen output indicator hasil belajar dan hambatan belajar siswa, temuan-temuan tersebut adalah: (1) ada perbedaan yang signifikan dalam hal hambatan belajar siswa yang didalamnya mencakup minat, kondisi sosial ekonomi, interaksi guru, sarana dan prasarana, dan penyajian materi, (2) hasil belajar yang ditunjukkan di nilai raport siswa terlihat berada pada nilai di atas KKM mata pelajaran produktif multimedia namun rerata kelas masih pres pada nilai KKM. Selanjutnya temuan-temuan di atas, disusun menjadi proposisi tentang proses pelaksanaan pembelajaran mata pelajaran produktif Kompetensi Keahlian Multimedia di SMK Negeri 1 Grati, yang diformulasikan sebagai berikut. Proposisi: proses pelaksanaan pembelajaran mata pelajaran produktif Kompetensi Keahlian Multimedia di SMK Negeri 1 Grati menghasilkan hasil belajar yang cukup ditunjukkan dengan nilai raport siswa yang berkisar pada nilai 76 yakni nilai KKM mata pelajaran produktif multimedia, namun siswa memiliki hambatan belajar yang tidak terlalu tinggi ditinjau dari beberapa faktor.

\section{PEMBAHASAN}

Selanjutnya akan dijabarkan pelaksanaan pembelajaran Produktif Kompetensi Keahlian Multimedia di SMK Negeri 1 Purwosari dan SMKN 1 Grati. Dengan komponen yang pertama dijabarkan yakni komponen konteks. Menurut Direktorat Jenderal Manajemen Pendidikan Dasar dan Mengengah (2008) pada ayat kedua pada bagian keempat dan kelima Keputusan Direktur Jenderal Manajemen Pendidikan Dasar dan Menengah Nomor: 251/C/KEP/MN/2008 menyatakan bahwa penambahan dan/atau perubahan kompetensi keahlian ditetapkan oleh Kepala Dinas Pendidikan sesuai dengan kewenangannya. Kabupaten Pasuruan menentukan bahwa pendirian kompetensi keahlian baru di sebuah SMK idealnya mengacu pada rencana strategis (renstra) yang me- 
rupakan penjabaran dari rencana jangka panjang dan menengah daerah sebuah kota atau kabupaten. Rencana strategis Kabupaten Pasuruan mengenai pendirian sebuah kompetensi keahlian di SMK mengacu pada beberapa hal, yaitu: (1) kebutuhan tenaga kerja DUDI, (2) potensi wilayah atau daerah setempat, (3) peningkatan angka partisipasi kasar siswa, (4) pendayagunaan sumber daya daerah, dan (5) pendayagunaan SDM di suatu daerah.

Penyelenggaraan urusan pendidikan sebagai salah satu kewenangan daerah menjadi sangat penting karena merupakan salah satu fungsi pelayanan dasar masyarakat. Permasalahan pendidikan merupakan aspek penting dari daerah hingga nasional. Penyusunan RPJM Daerah juga terdapat visi pembangunan untuk membentuk pendidikan yang berkualitas. Sebelum RPJM Daerah dijabarkan dalam kegiatan tahunan, yang pertama kali harus dilakukan implementor adalah menyusun renstra (rencana strategis) yang berisi analisis birokratif untuk mencapai tujuan yang termuat dalam RPJM. Kegiatan menyusun renstra oleh unit kerja pemerintah daerah termasuk dinas pendidikan sebenarnya merupakan suatu keharusan untuk dilaksanakan (Paulus, 2013).

Dengan mengkaji perbandingan antara kelompok kasus substantif, di mana substantif menjadi penghubung yang strategis dalam memfokuskan dan menyusun teori formal berdasarkan pada data, maka penelitian ini ditelaah berdasarkan data temuan tentang latar belakang didirikannya Kompetensi Keahlian Multimedia di SMK. Berdasarkan fakta temuan penelitian pada situs dalam komponen konteks dan indikator latar belakang pendirian sebuah kompetensi keahlian, bahwa kepala sekolah harus mengetahui apa yang menjadi rencana strategi di masing-masing kota/kabupaten, karena dari rencana strategi tersebut nantinya akan dijabarkan lagi menjadi itemitem apa yang dijadikan dasar penentuan dari pendirian sebuah kompetensi keahlian.

Pentingnya gagasan dalam dalam perencanaan pendirian kompetensi keahlian harus juga melibatkan ketersediaan sarana yang akan menunjang proses pembelajaran siswa (Lunenburg, 2011). Menurut Nurtanto (2016), pengembangan SMK selayaknya memperhatikan karakteristik daerah setempat. Dengan demikian, karakteristik daerah merupakan ciriciri khusus yang melekat pada daerah tersebut, menandai pada suatu daerah atau potensi yang diunggulkan dan membedakan dengan daerah lain. Hal ini dapat disimpulkan bahwa setiap kota/kabupaten bisa saja memiliki kriteria yang berbeda berdasarkan rencana strategi yang kemungkinan berbeda pula dari masing-masing kota/kabupaten dan berdampak pada kebijakan pendirian kompetensi keahlian baru di sebuah SMK.

Pendirian kompetensi keahlian baru, tidak serta merta dapat dibuka secara langsung tanpa adanya pengajuan kepada dinas pendidikan setempat. Di era otonomi daerah, tugas, fungsi, dan peran Dinas Pendidikan Kabupaten/Kota jauh lebih besar dibandingkan dengan era sebelumnya. Dinas Pendidikan Kabupaten/Kota yang sebelumnya merupakan pelaksana kebijakan pendidikan pemerintah pusat dan propinsi, kini diberi kewenangan mengembangkan kebijakan pendidikan untuk kabupaten/kotanya (Andriani, 2008).

Setelah diperhitungkan latar belakang pendiriannya, selanjutnya dilakukan analisis SWOT. Disamping itu pendirian kompetensi keahlian baru didasarkan pada pertimbangan yang fokusnya mengacu pada kebutuhan pasar, baik dari masyarakat sekitar, maupun tuntutan pemenuhan tenaga pekerja DUDI yang berhubungan dengan Kompetensi Keahlian Multimedia. Selain beberapa hal yang sifatnya menjawab kebutuhan pasar dalam mendirikan sebuah kompetensi keahlian, yang perlu diperhatikan adalah keberada- 
an kompetensi keahlian yang sama di sekolah lain yang ada di wilayah sekolah itu sendiri. Berdasarkan fakta temuan penelitian pada kedua situs dalam komponen konteks, keduanya melakukan analisis terhadap kebutuhan dasar pendirian sebuah kompetensi keahlian, mulai dari kebutuhan pasar, masyarakat, tenaga kerja yang ada di DUDI, hingga masing-masing item penjabaran dari SWOT, yakni strong, weakness, opportunity, dan treath.

Hal ini sejalan dengan apa yang tertuang di BSNP Tahun 2006 tentang Analisis konteks dalam pelaksanaan penyusunan KTSP berwujud evaluasi diri (self evaluation) terhadap sekolah. Hal itu dapat dilakukan dengan menerapkan pendekatan SWOT (strengths, weaknesses, opportunities, dan threats). Dalam hal ini dapat diterapkan kajian lingkungan internal untuk memahami strengths atau kekuatan dan weaknesses atau kelemahan, serta kajian lingkungan eksternal untuk mengungkap opportunities atau peluang dan threats atau tantangan. Sehingga SMKN 1 Purwosari dan SMKN 1 Grati dalam hal sebelum membentuk atau mendirikan sebuah kompetensi keahlian salah satu syaratnya yaitu melakukan analisis SWOT dan analisis kebutuhan pasar adalah sesuai dengan standar yang ada pada BSNP dikarekanan pendirian kompetensi keahlian itu termasuk dalam analisis konteks pada pelaksanaan penyusunan KTSP (BNSP, 2006).

Selain mengacu pada rencana strategis Kabupaten Pasuruan, sebelum mendirikan sebuah kompetensi keahlian baru di SMK idealnya dilakukan studi kelayakan wilayah mulai dari daerah keberadaan SMK kemudian meluas ke wilayah kabupaten. Kondisi geografis siswa pada suatu kompetensi keahlian, erat kaitannya dengan keberadaan DUDI yang ada di wilayah sekitar sekolah, karena hal tersebut menjadi pengaruh terhadap kondisi sosial ekonomi siswa pada sebuah kom- petensi keahlian. Berdasarkan fakta temuan penelitian pada kedua situs dalam komponen konteks, keduanya melakukan studi kelayakan wilayah, namun perbedaannya adalah di SMK Negeri 1 Grati lebih fokus pada keberadaan DUDI yang ada di wilayah sekolah dalam hal ini meluas hingga Kabupaten Pasuruan, sedangkan SMK Negeri 1 Purwosari lebih sederhana yaitu targetnya adalah minimum $10,00 \%$ dari jumlah keseluruhan siswa Kompetensi Keahlian Multimedia adalah harus diambil dari masyarakat yang berdomisili di sekitar sekolah.

Komponen yang kedua dijabarkan adalah komponen input. Diketahui bahwa sumber daya manusia (SDM) sebagai penyelenggara pendidikan yang memiliki kompetensi tinggi dan bekerja secara profesional sesuai bidangnya sangatlah dibutuhkan. Guru merupakan SDM yang memegang peranan penting dalam proses pembelajaran di SMK. Karena hanya dari guru profesional dan sekolah berkualitaslah SDM yang berkualitas dapat diperoleh (Wuryandini, 2014).

Depdiknas (2003) dalam UndangUndang Sistem Pendidikan Nasional Nomor 20 Tahun 2003 tidak menjabarkan lebih jauh seperti apa yang dimaksud dengan guru profesional. Pasal 42 ayat 1 menyatakan bahwa seorang guru harus memiliki kualifikasi minimum dan sertifikasi sesuai dengan jenjang kewenangan mengajar yang ketentuannya diatur dalam peraturan pemerintah. (Pemerintah RI, 2005) dalam Peraturan Pemerintah Nomor 19 Tahun 2005 tentang Standar Nasional Pendidikan (SNP), tidak dinyatakan secara jelas guru sebagai jabatan dan atau pekerjaan profesional. Pasal 28 ayat 3 hanya menyatakan bahwa seorang guru sebagai agen pembelajaran diharuskan mempunyai kompetensi profesional dan kompetensi lain seperti kompetensi pedagogik, kompetensi kepribadian, kompetensi profesional, dan kompetensi sosial. Selanjutnya dinyatakan juga bah- 
wa setiap pendidik pada setiap jenjang pendidikan harus memiliki kualifikasi akademik minimum D4 atau sarjana pada bidang atau program pendidikan yang sesuai dengan bidang yang diajarkan atau sesuai dengan jenjang tempat mengajar dan harus pula memiliki sertifikat profesi guru (Pasal 29).

Hal tersebut yang menyebabkan tidak adanya standar khusus yang dimiliki oleh kedua sekolah dalam hal rekrutmen guru produktif sebagai salah satu kunci dalam menjaga kualitas pelaksanaan pembelajaran produktif Kompetensi Keahlian Multimedia di SMK. Di sisi lain menurut (Choi dan Tang, 2011) Para pembuat kebijakan juga harus mempelajari hubungan atar guru dan standar penerimaan guru sebelum memulai mengajar secara mendalam.

Guru menjadi garda terdepan dalam penyelenggaraan pendidikan di Indonesia. Keberhasilan pendidikan ada di tangan guru. Guru adalah individu yang berhadapan langsung dengan peserta didik di kelas dalam pembelajaran. Guru memiliki peran penting untuk membuat peserta didik berkualitas baik akademis, keahlian, kematangan emosional, moral serta spiritual. Untuk menunjang semua itu, diperlukan sosok guru yang memiliki kualifikasi, kompetensi, serta dedikasi yang tinggi dalam menyelenggarakan tugasnya (Alawiyah, 2013).

Menurut (Zhang, 2011) setiap calon guru harus diseleksi juga dari segi pengalaman mengajar di sekolah ataupun lembaga pendidikan lain, supaya dapat menunjukkan bahwa guru dapat berbaur dengan calon siswa yang akan dididik. Sedangkan menurut (Suwandi, 2016) setiap calon guru produktif di SMK selain memiliki ijazah S1 dan D4, guru harus memiliki sertifikat kompetensi dan sertifikat profesi yang dikeluarkan oleh perguruan tinggi yang memiliki program pengadaan tenaga kependidikan dan terakreditasi minimal B sebagai bukti formal pengaku- an kewenangan bagi yang telah memiliki kualifikasi akademik minimal dan sertifikat kompetensi. Selain guru, siswa juga merupakan salah satu SDM yang penting dalam sistem manajemen pendidikan di sekolah. Dalam dunia pendidikan, siswa merupakan komponen mentah, artinya siswa dengan segala karakteristik awalnya merupakan subjek yang akan dididik melalui berbagai kegiatan pembelajaran sehingga menjadi keluaran atau lulusan sebagaimana yang diharapkan (Bafadal, 2003:9).

Pada dasarnya seluruh komponen pembelajaran di sekolah harus dijaga dan selalu ditingkatkan kualitasnya supaya hasil atau output yang dihasilkan juga akan baik. Sama seperti guru, input-an siswa juga harus dijaga kualitasnya. Di SMK Negeri 1 Purwosari sangat selektif dalam hal penerimaan siswa Kompetensi Keahhlian Multimedia, hal ini ditunjukkan dengan adanya tes khusus untuk masing-masing minat calon siswa, termasuk minat pada Kompetensi Keahlian Multimedia. Tetapi di SMK Negeri 1 Grati tidak demikian karena belum ada tes khusus hanya saja persyaratan untuk calon siswa tidak boleh buta warna dan harus memiliki kemampuan dasar dalam bidang IT.

Berdasarkan fakta yang ada di dua sekolah, maka dianggap perlu untuk ada tes khusus peminatan disamping juga digabungkan dengan persyaratan yang diajukan di awal pendaftaran. Sehingga nantinya, akan diperoleh hasil yang signifikan dalam nilai setiap tes siswa yang kemudian akan dijadikan acuan untuk penerimaan siswa di Kompetensi Keahlian Multimedia.

Input pendidikan dikatakan berkualitas apabila input sekolah dilakukan secara harmonis salah satunya input siswa, sehingga mampu menciptakan calon siswa yang berkualitas. Adapun Indikator kualitas input siswa berkualitas adalah: (1) Nilai NEM siswa yang mendaftar di 
sekolah mengalami peningkatan, (2) Saat penerimaan siswa baru sekolah tidak pernah kekurangan siswa, dan (3) adanya tes yang dilakukan saat penerimaan calon siswa sesuai bidangnya (Hermawan, 2013).

Berdasarkan pernyataan di atas, dapat dikatakan bahwa penerimaan guru dan siswa sebagai input-an SDM Kompetensi Keahlian Multimedia di SMKN 1 Purwosari dan SMKN 1 Grati perlu adanya perumusan standar yang dapat digunakan oleh SMK kebanyakan yang ditujukan untuk menjaga kualitas pelaksanaan pembelajaran Produktif Kompetensi Keahlian Multimedia.

Sumber daya lain juga dibutuhkan dalam rangka membantu terlaksananya sebuah proses pembelajaran produktif yang baik pada Kompetensi Keahlian Multimedia di masing-masing sekolah, seperti pendanaan dan sarana prasarana yang menunjang proses pembelajaran produktif Kompetensi Keahlian Multimedia. Pendanaan yang ada di SMKN 1 Purwosari dan SMKN 1 Grati dapat dikatakan keduanya bergantung pada dana yang diperoleh dari Dinas Pendidikan, meskipun SMKN 1 Purwosari pernah menjalin kerjasama dengan IJI dalam hal pendanaan sarana prasarana.

Pada tataran teknis, sistem pendistribusian dana dari Dinas Pendidikan dapat digolongkan menjadi dua jenis, yaitu: sistem langsung dan sistem tidak langsung. Distribusi langsung dalam konteks anggaran sarana dan prasarana sekolah berarti bahwa anggaran yang telah dialokasikan langsung diserahkan ke sekolah untuk dikelola secara mandiri. Sementara distribusi tidak langsung berarti pengelolaan anggaran dilakukan melalui mekanisme tender terlebih dahulu. Selanjutnya, pemenang tender yang mengelola anggaran dan sekolah tinggal menerima sarana dan prasarana.

Selanjutnya setelah sarana dan prasarana telah diterima oleh sekolah, distri- busi dapat dilakukan secara langsung maupun tidak langsung. Menggunakan sistem distribusi langsung berarti sarana dan prasarana sekolah yang sudah diterima dan diinventarisasikan langsung disalurkan ke unit atau personel sekolah yang membutuhkan tanpa melalui proses penyimpanan. Sebaliknya, sistem distribusi tidak langsung berarti sarana dan prasarana sekolah yang sudah diterima dan diinventarisasikan tidak secara langsung disalurkan, melainkan harus disimpan terlebih dahulu di gudang penyimpanan secara teratur (Tanggela, 2013:5).

Faktanya, kedua sekolah dalam hal pendistribusian sarana prasarana untuk menunjang proses pembelajaran produktif multimedia memakai sistem pengajuan dari kompetensi keahlian, barulah kemudian diberikan sesuai dengan pengajuan. Hal tersebut jika disesuikan dengan penjelasan sebelumnya maka termasuk jenis pendistribusian bersifat tidak langsung karena tidak secara keseluruhan langsung diberikan melainkan melalui proses pengajuan. Perbedaan dari kedua sekolah adalah di SMK Negeri 1 Purwosari merasa sudah cukup memenuhi dalam hal pemenuhan sarana prasarana bagi siswa Kompetensi Keahlian Multimedia, sedangkan SMK Negeri 1 Grati merasa belum memenuhi terutama dalam hal pemenuhan alat praktek yang jumlahnya lebih sedikit dibandingkan jumlah siswa.

Tersedianya sarana dan prasarana yang memadai tentunya akan sangat membantu dalam pelaksanaan pembelajaran produktif multimedia di kedua SMK. Zulfikar (2007:20) mengemukakan bahwa sarana dan prasarana praktik adalah segala sesuatu yang berhubungan langsung dengan proses belajar mengajar praktik seperti fasilitas ruangan, perabotan, peralatan praktik (alat ukur dan alat tangan), bahan praktik, media belajar untuk mencapai tujuan pembelajaran.

Dari penjelasan di atas ketika sarana dan prasarana dalam praktik tidak tercu- 
kupi dengan baik maka akan mempersulit siswa untuk melaksanakan praktik. Mata pelajaran produktif di SMK, 70,00\% bersifat praktik, maka jika dalam hal praktik siswa tidak terpenuhi kebutuhannya, jelas akan menghambat proses praktik. Hal ini sesuai dengan hasil penelitian Rosivia (2014) mengemukakan bahwa tersedianya sarana prasarana yang siap pakai saat dibutuhkan juga akan mendukung proses pembelajaran siswa terutama saat praktik. Ketika ketersediaan sarana prasana sudah mencukupi, maka dilanjutkan dengan proses pengelolaan yang baik juga agar dapat di gunakan dengan jangka waktu yang lebih lama, selain itu pengelolaan sarana dan prasarana bertujuan agar tercipta suatu kondisi yang kondusif, nyaman, dan aman dalam proses pembelajaran.

Komponen yang ketiga dijabarkan adalah komponen proses. Evaluasi proses diyakini sebagai jaminan produk berkualitas (Hussain, 2011). Mendiknas (2007) pada Permendiknas No. 41 Tahun 2007 tentang Standar Proses menyebutkan bahwa beban kerja guru mencakup kegiatan pokok merencanakan pembelajaran, melaksanakan pembelajaran, menilai hasil pembelajaran, membimbing dan melatih peserta didik, serta melaksanakan tugas tambahan. Pelaksanaan pembelajaran produktif Kompetensi Keahlian Multimedia pada kedua SMK yang ada di Kabupaten Pasuruan dimulai dari tersedianya dokumen pembelajaran dan dilanjutkan dengan mengimplementasikan dokumen pembelajaran tersebut ke dalam proses pembelajaran. Dokumen pembelajaran yang harus disiapkan pada saat guru melaksanakan pembelajaran produktif.

Pelaksanaan pembelajaran produktif sebagaimana yang tercantum di dalam rencana program pembelajaran (RPP) dibagi menjadi tiga bagian yakni kegiatan pendahuluan, kegiatan ini atau pembentukan kompetensi, dan kegiatan penutup.
Semua kegiatan dicatat pada agenda pembelajaran yang terdiri atas agenda kelas dan agenda guru. Agenda kelas digunakan untuk mencatat seluruh kegiatan/materi pembelajaran di kelas/laboratorium/bengkel, sedangkan agenda guru digunakan untuk mencatat seluruh kegiatan guru dalam melaksanakan pembelajaran.

Hal ini sesuai dengan hasil penelitian Suryanto (2012) tentang pelaksanaan pembelajaran praktek produktif di SMK yang menyatakan bahwa kegiatan pembelajaran, terutama untuk pembelajaran praktek produktif dimulai sejak awal kelas X sampai akhir kelas XII. Mata pelajaran produktif (kejuruan) adalah merupakan inti atau ciri khusus bagi SMK, hal inilah yang membedakan dengan jenis sekolah lain yang setara. Proses pembelajaran produktif di SMK meliputi tiga hal yakni kegiatan pembuka atau pendahuluan, kemudian kegiatan pengembangan kompetensi, dan dilanjutkan dengan kegiatan penutup. Proses pelaksanaan pembelajaran produktif di SMK bias dilaksanakan dengan berbagai macam model pembelajaran menurut Suryanto, 2012. Pembelajaran produktif di SMK dapat dilaksanakan dengan menggunakan model pembelajaran berbasis kompetensi, berbasis produksi, dan berbasis industri.

Proses penilaian pada pembelajaran produktif merupakan penilaian yang dilakukan guru secara langsung, untuk mengetahui tingkat pencapaian dan kompetensi yang telah ditentukan oleh peserta didik. Sanjaya (2011:350) menyatakan penilaian merupakan bagian integral dalam proses pembelajaran yang dilakukan sebagai proses pengumpulan dan pemanfaatan informasi yang menyeluruh tentang hasil belajar yang diperoleh siswa untuk menetapkan tingkat pencapaian dan penguasaan kompetensi seperti yang ditentukan dalam kurikulum dan sebagai umpan balik untuk perbaikan proses pembelajaran. 
Hasil penelitian di lapangan pada kedua situs menunjukkan bahwa penilaian yang dilakukan pada mata pelajaran produktif meliputi: (1) penilaian tertulis, lisan dan praktik (proyek, produk maupun unjuk kerja), (2) penilaian dilaksanakan pada setiap akhir standar kompetensi, (3) kriteria siswa dikatakan kompeten atau lulus apabila memenuhi nilai minimal sama dengan 76, dan (4) bentuk penilaian terhadap siswa berupa ulangan harian, tengah semester, akhir semester dan kenaikan kelas.

Hal ini sesuai dengan Permendiknas No. 20 Tahun 2007 tentang Standar Penilaian Pendidikan yang menyatakan penilaian hasil belajar oleh pendidik dapat menggunakan menggunakan berbagai teknik penilaian berupa tes (tes tertulis, tes lisan, dan tes praktik atau tes kinerja), observasi, penugasan perseorangan atau kelompok, dan bentuk lain yang sesuai dengan karakteristik kompetensi dan tingkat perkembangan peserta didik. Disamping itu dinyatakan pula bahwa bentuk ulangan berupa ulangan harian, ulangan tengah semester, ulangan akhir semester, dan ulangan kenaikan kelas dilakukan oleh pendidik di bawah koordinasi satuan pendidikan (Mendiknas, 2007a).

Strategi evaluasi pada intinya merupakan bagian integral dalam pembelajaran program produktif, karena sistem evaluasi telah dirumuskan dalam rancangan pembelajaran. Hal ini sesuai dengan hasil penelitian oleh Setyohandani (2013) menyatakan bahwa evaluasi hasil pembelajaran merupakan salah satu bagian dalam proses pendidikan dan pelatihan, artinya perencanaan dan pelaksanaan penilaian harus senantiasa mengacu dan sejalan dengan prinsip-prinsip pendidikan dan pelatihan kejuruan. Pelaksanaan penilaian/evaluasi hasil pembelajaran program produktif dapat diterapkan dalam tahap: (1) evaluasi pembinaan (formative evaluation); (2) evaluasi hasil belajar (summative evaluation); dan (3) evaluasi penguasaan kompetensi (competence evaluation). Formative evaluation merupakan proses penilaian yang dilakukan guru sebagai bagian tak terpisahkan dari proses pembelajaran.

Komponen yang terakhir dijabarkan adalah komponen produk. Komponen produk dalam penelitian ini adalah hasil yang diperoleh selama proses kegiatan belajar mengajar berlangsung, yang meliputi hasil afektif, kognitif dan psikomotorik yang secara keseluruhan tertuang dalam raport hasil belajar siswa. Dari ketiga aspek ini, Kriteria Ketuntasan Minimal (KKM) yang ditetapkan sekolah adalah 76.

Sesuai dengan tujuan penelitian, dalam komponen product hasil yang diperoleh selama KBM berlangsung memegang peranan penting, sebagaimana $\mathrm{Me}$ nurut Bloom dalam Hamalik (2004:87), tujuan pembelajaran dibedakan menjadi tiga aspek, yaitu: (1) aspek kognitif (cognitive domain), meliputi: pengenalan, pengetahuan, pemahaman, analisis, sintesa, dan evaluasi, (2) aspek afektif (affective domain), meliputi: sikap, perasaan emosi dan karakteristik moral yang merupakan aspek psikologis siswa, (3) aspek psikomotor (psychomotor domain), adalah penguasaan keterampilan dengan didukung oleh keutuhan anggota badan yang akan terlibat dalam berbagai jenis kegiatan. Aspek psikomotor meliputi: persepsi, kesiapan, mekanisme, keterampilan, dan adaptasi.

Pada kedua SMK terdapat perbedaan hasil belajar, hasil belajar di SMK Negeri 1 Grati yang bisa dikatakan rerata berada pada angka kriteria kecakapan minimum bisa jadi dikarenakan dari berbagai hal seperti minimnya sarana prasarana, ataupun kurangnya tenaga pendidik yang linier. Beberapa penelitian terkait dengan pengaruh pengadaan sarana prasarana terhadap proses pembelajaran siswa dapat dilihat pada penelitian yang dilakukan 
oleh Tukiman (2009) menyatakan bahwa jumlah peralatan praktik sangat berpengaruh terhadap proses pembelajaran praktik. Jumlah peralatan praktik yang memadai dapat menjamin terselenggaranya praktik dengan lebih leluasa, sehingga siswa memiliki lebih banyak pengalaman. Begitu juga dengan hasil penelitian Fauziati (2009) menyatakan bahwa ada hubungan yang positif antara kondisi sarana terhadap pencapaian hasil belajar, hubungan yang positif menunjukkan bahwa apabila sarana mempunyai nilai tinggi maka hasil belajar akan tinggi pula.

Beberapa penelitian terkait dengan pengaruh kualifikasi kompetensi guru terhadap proses pembelajaran dapat dilihat pada penelitian yang dilakukan oleh Winarto (2011) menyatakan bahwa terdapat fakta di lapangan yang menunjukkan kualifikasi pendidikan guru di sekolah bertaraf internasional di Malang masih belum linier atau sesuai dengan ilmu yang dia pelajari sebelumnya artinya guru yang tidak berasal dari tamatan Pendidikan Teknik Informatika atau yang serumpun akan mengalami kesulitan mengajar di SMK Jurusan Multimedia, sehingga dapat dipastikan dia tidak dapat bekerja secara profesional.

Kualifikasi akademik yang dimiliki guru juga akan mempengaruhi kompetensi dan profesionalisme dalam melaksanakan tugas mengajar. Jenis kompetensi ini menurut peraturan menteri pendidikan nasional Republik Indonesia Nomor 16 Tahun 2007 terdiri dari empat kompetensi yakni kompetensi pedagogik, kompetensi kepribadian, kompetensi profesional, kompetensi sosial. Tidak terpenuhnya kualifikasi akademik guru akan berimbas terhadap output pembelajaran (Mendiknas, 2007).

Seiring dengan terlihatnya bukti nyata pada hasil belajar siswa pada Pelaksanaan pembelajaran mata pelajaran produktif multimedia pada dua SMK di Kabupaten Pasuruan tidak lepas dari be- berapa hambatan atau kendala. Untuk mengatasi hambatan yang berbeda di masing-masing sekolah, sekolah mengupayakan dalam hal mengefektifkan penggunaan sumber daya dan dana yang ada, sehingga jika ada kekurangan dapat segera diketahui.

\section{SIMPULAN DAN SARAN}

Berdasarkan hasil temuan dan analisis lintas situs dengan memperhatikan tujuan penelitian, maka dapat disimpulkan sebagai berikut. Latar belakang pendirian Kompetensi Keahlian Multimedia di kedua sekolah memiliki persamaan samasama berdasarkan studi kelayakan wilayah, dan melakukan beberapa analisis seperti analisis SWOT di SMKN 1 Purwosari, dan analisis kebutuhan masyarakat di SMKN 1 Grati. Kondisi geografis sosial ekonomi siswa juga menjadi salah satu pertimbangan didirikannya Kompetensi Keahlian Multimedia. Daya dukung masyarakat di SMKN 1 Purwosari terbukti dengan adanya media pendukung seperti tempat-tempat yang bisa dijadikan sebagai tempat prakerin dan bekerja siswa setelah lulus. Sedangkan di SMKN 1 Grati hanya berdasarkan survei dan angket yang disebar sebelum pendirian Kompetensi Keahlian Multimedia.

Input SDM dalam konteks penerimaan guru SMK terdapat perbedaan antara SMKN 1 Grati dan SMKN 1 Purwosari. Perbedaannya terletak pada syarat latar belakang pendidikan guru. Hanya guru yang lulusan universitas negeri yang diterima menjadi guru produktif, sedangkan SMKN 1 Grati tidak, asalkan linier dengan bidang ajarnya dapat diterima menjadi guru produktif. Untuk siswa terdapat perbedaan antara SMKN 1 Grati dan SMKN 1 Purwosari. Perbedaannya di SMKN 1 Purwosari ada tes khusus peminatan sesuai kompetensi keahlian, sedangkan di SMKN 1 Grati tidak. Sumber daya lain seperti dana, peralatan, perleng- 
kapan, dan bahan di kedua sekolah juga terdapat perbedaan mulai dalam hal sumber, pengelolaan, dan pendistribusian.

(3) Pelaksanaan pembelajaran produktif multimedia dilaksanakan berdasarkan tiga tahapan: (1) perencanaan pembelajaran produktif dilakukan secara periodik setiap satu tahun sekali; (2) pelaksanaan pembelajaran produktif dilakukan bentuk pemberian prosentase materi SK/ KD mata pelajaran produktif setiap semester disesuaikan kondisi masing-masing sekolah; (3) evaluasi dan penilaian pembelajaran produktif terhadap peserta didik berupa penilaian tertulis, lisan dan praktik (proyek, produk maupun unjuk kerja), penilaian dilaksanakan pada setiap akhir standar kompetensi; (4) Hasil belajar mata pelajaran Produktif Multimedia yang ada di SMKN 1 Grati dan SMKN 1 Purwosari memiliki perbedaan. Perbedaannya di SMK Negeri 1 Purwosari nilai siswa berada pada rerata atas, sedangkan di SMK Negeri 1 Grati berada pada kisaran standar minimum. Tinggi rendahnya hasil belajar siswa dipengaruhi seberapa besar hambatan atau permasalahan yang dimiliki oleh siswa saat pelaksanaan pembelajaran mata pelajaran Produktif Multimedia berlangsung.

\section{DAFTAR RUJUKAN}

Alawiyah, F. 2013. Peran Guru dalam Kurikulum 2013. Jurnal Aspirasi, 4(1): 65-74.

Andriani, D.E. 2008. Kajian Konseptual Restrukturisasi Dinas Pendidikan Kota/Kabupaten di Era Otonomi Daerah. Jurnal Manajemen Pendidikan, 4(1): 20-33.

Bafadal, I. 2003. Manajemen Peningkatan Mutu Sekolah Dasar. Jakarta: Bumi Aksara.

BNSP. 2006. Kurikulum Tingkat Satuan Pendidikan. Jakarta: Dirjen.

Choi, P. \& Tang, S. 2011. Satisfied and Dissatisfied Commitment: Teachers in Three Generations. Australian Journal of Teacher Education, 36(7): 45-75.

Depdiknas. 2003. Undang-undang Nomor 20 Tahun 2003, tentang Sistem Pendidikan Nasional. Jakarta: Depdiknas.

Direktorat Jenderal Manajemen Pendidikan Dasar dan Menengah. 2008. Keputusan Direktur Jenderal Manajemen Pendidikan Dasar dan Menengah Nomor 251/C/KEP/MN/ 2008, tentang Spektrum Keahlian Pendidikan Menengah Kejuruan. Jakarta: Ditjen Manajemen Ditdasmen.

Djohar, A. 2003. Pendidikan Teknologi Kejuruan dalam Rujukan Filsafat Teori, dan Praktis Ilmu Pendidikan. Bandung: UPI Pers.

Fauziati, E. 2009. Introduction to Methods and Approaches in Second or Foreign Language Teaching. Surakarta: Era Pustaka Utama.

Hamalik, O. 2004. Proses Belajar Mengajar. Jakarta: Bumi Aksara.

Hermawan, D. 2013. Manajemen Kesiswaan untuk Meningkatkan Kualitas Input dan Output Siswa serta Relevansinya dengan Studi Kependidikan Islam. Jurnal Manajemen Pendidikan, 24(1): 32-43.

Hussain, A. 2011. Evaluation of Curriculum Development Process. International Journal of Humanities and Social Science, 1(14): 263-271.

Kaufman, R. \& Thomas, S. 1980. Evaluation without Fear. London: New Viewpoint.

Lunenburg, LC. 2011. Curriculum Development: Inductive Models. Schooling, 2(1): 1-8.

Mawarsari, V.D. \& Prihaswati, M. 2014. Evaluasi Pembelajaran Matematika Menggunakan Model CIPP pada Kejar Paket B Kota Semarang. Prosiding Seminar Nasional dan Internasional, 1(2): 42-47. 
Mendiknas. 2007. Permendiknas Nomor 41 Tahun 2007, tentang Standar Proses. Jakarta: Mendiknas.

Mendiknas. 2007a. Permendiknas Nomor 20 Tahun 2007, tentang Standar Penilaian Pendidikan. Jakarta: Mendiknas.

Mendiknas. 2007b. Peraturan Menteri Pendidikan Nasional Nomor $16 \mathrm{Ta}$ hun 2007, tentang Standar Kualifikasi Akademik dan Kompetensi Guru. Jakarta: Mendiknas.

Mulyatiningsih, E. 2012. Metode Penelitian Terapan Bidang Pendidikan. Bandung: Alfabeta.

Nurtanto, M. 2016. Menyiapkan Pendidikan Kejuruan Berbasis Kearifan Lokal yang Berdaya Saing. Jurnal Ilmiah Pendidikan Teknik Elektro, 1(1): 59-66.

Paulus, R.D. 2013. Implementasi Kebijakan Dinas Pendidikan Kabupaten Minahasa. Jurnal Ekskutif Universitas Sam Ratulangi Manado, 5(1): 114.

Pemerintah RI. 2005. Peraturan Pemerintah Nomor 19 Tahun 2005, tentang Standar Nasional Pendidikan (SNP). Jakarta: Pemerintah RI.

Rosivia. 2015. Peningkatan Pengelolaan Sarana Prasarana Pendidikan di SMP Negeri 10 Padang. Jurnal Administrasi Pendidikan UNP, 2(1): 636-831.

Sanjaya, W. 2011. Kurikulum dan Pembelajaran, Teori dan Praktik Pengembangan Kurikulum Tingkat Satuan Pendidikan (KTSP). Jakarta: Kencana Prenada Media Group.

Setyohandani, R. 2013. Strategi Evaluasi Pembelajaran Program Produktif SMK. Makalah disampaikan pada Seminar Nasional Evaluasi Pendidikan di Semarang pada tanggal 20 September 2013.

Suryanto, F. 2012. Pelaksanaan Pembelajaran Praktek Produktif di Sekolah Menengah Kejuruan. Jurnal Penelitian Ilmu Pendidikan, 5(2): 15-23.
Suwandi. 2016. Analisis Studi Kebijakan Pengelolaan Guru SMK dalam Rangka Peningkatan Mutu Pendidikan. Jurnal Pendidikan Teknologi dan Kejuruan, 23(1): 90-100.

Tanggela, M. 2013. Analisis Implementasi Kebijakan Pengelolaan Sarana dan Prasarana Sekolah di SMP Negeri 2 Batu. Jurnal Kebijakan dan Pengembangan Pendidikan, 1(1): 26-34.

Tukiman. 2009. Situasi Bengkel dan Kondisi Peralatan Praktik Pemesinan SMK Swasta di Wilayah Gerbangkertosusila. Tesis tidak diterbitkan. Malang: Pascasarjana Universitas Negeri Malang.

Winarto, S. 2011. Studi tentang Kompetensi Profesional Guru Mata Diklat Produktif Teknik Komputer dan Jaringan SMK Bertaraf Internasional di Malang. Tesis tidak diterbitkan. Malang: Pascasarjana Universitas Negeri Malang.

Wuryandini, E. 2014. Analisis Permasalahan dan Kebutuhan Pengembangan Keprofesian Berkelanjutan Guru SMK Bidang Keahlian Bisnis dan Manajemen Pascasertifikasi di Kota Semarang. Jurnal Manajemen Pendidikan, 9(2): 108-119.

Zhang, G. 2011. Using the Context, Input, Process, and Product Evaluation Model (CIPP) as a Comprehensive Framework to Guid the Planning, Implementation, and Assessment of Service-learning Programs. Journal of Higher Education Outreach and Engagement, 15(4): 57-83.

Zulfikar. 2007. Kontribusi Pengalaman Diklat dan Kelengkapan Sarana Prasarana Praktik di SMK terhadap Kinerja Guru Bidang Keahlian Teknik Elektro SMK di Propinsi Riau. Tesis tidak dipublikasikan. Malang: Pascasarjana Universitas Negeri Malang. 